\title{
Paulina Guzik
}

Uniwersytet Papieski Jana Pawła II w Krakowie

\section{BLISKI WSCHÓD BEZ CHRZEŚCIJAN? WSPÓłCZESNE LUdoBóJSTWO WYZNAWCóW CHRYSTUSA NA TERENIE IRAKU I SYRII}

\begin{abstract}
Middle East without Christians? Contemporary genocide of the followers of Jesus Christ in Iraq and Syria. Christians inhabited territories of todays Iraq and Syria, laying on what was anciently Mesopotamia from the very time of Jesus Christ. The persecution of Christianity had begun when Islam arose and lasts to this day. In contemporary times persecution became especially regular, bloody and intolerable since 2003 when American forces invaded Iraq, toppling not only the bloody dictator but also local status quo that kept the country and it's society in one piece. When jihadist fighters announced the creation of an Islamic State across Iraq and Syria in June 2014, persecution turned into genocide. Christians, along with other religious minorities, but also Shia Muslims (being in the opposition to IS) are facing mass killings in most brutal of possible ways, but also they face deliberate infliction on the group conditions of life, calculated to bring about its physical and psychological destruction. Christian children are forcibly transferred to Islamic locations. Those terms are the core of the so-called „Genocide convention“. Along with trying to answer two major questions in this article - whether ISIS' actions are to be called genocide and whether the Middle East is being wiped out of christianity, I am trying to focus on the presentation of life conditions of Christians in Iraq and Syria and consequences of the deadly march of ISIS fighters through the Middle East.
\end{abstract}

Bliski Wchód bez chrześcijan? Współczesne ludobójstwo wyznawców Chrystusa na terenie Iraku i Syrii. Terytoria dzisiejszego Iraku, niegdyś Mezopotamii, od pierwszych wieków zamieszkiwane były przez chrześcijan. Od czasu wzrostu potęgi religii islamskiej chrześcijanie doświadczali na tych terenach prześladowań. Współcześnie najbardziej dotkliwe prześladowania chrześcijan na tych terenach rozpoczęły się w 2003 roku, kiedy wraz z Amerykanami w Iraku pojawił się chaos 
i próżnia władzy. Całkowicie odsunięci od władzy Sunnici - jednym z nich był Saddam Hussein - odbudowali swoją pozycję w Iraku, wstępując w szeregi sunnickiego Państwa Islamskiego. Od czasu jego powstania w czerwcu 2014 roku chrześcijanie, wraz z innymi mniejszościami religijnymi na terenach Iraku i Syrii są regularnie i masowo zabijani, ludność ta zmuszona jest do życia w warunkach uwłaczających godności, bez odpowiedniej opieki zdrowotnej i pracy, chrześcijańskie dzieci są odbierane rodzicom i oddawane na wychowanie w bazach Państwa Islamskiego. Wszystkie te czynniki noszą znamiona ludobójstwa wymienione w Konwencji ws. zapobiegania i karania zbrodni ludobójstwa. Artykuł ten jest próbą odpowiedzi na pytanie, czy w Iraku i Syrii dochodzi do ludobójstwa mniejszości chrześcijańskiej i czy istnieje obawa całkowitego wyparcia chrześcijan z Bliskiego Wschodu. Aby udzielić odpowiedzi na zadane pytania, przytoczę świadectwa osób mieszkających w Iraku i cierpiących prześladowania, posłużę się także opiniami ekspertów i analizami dotyczącymi przyszłości Bliskiego Wschodu i perspektyw na pokonanie Państwa Islamskiego.

Keywords Christianity, genocide, persecution of Christians, Iraq, Syria, ISIS, Middle East chrześcijaństwo, ludobójstwo, prześladowanie chrześcijan, Irak, Syria, ISIS, Bliski Wschód

Na terenach biblijnej Mezopotamii, dziś Iraku i Syrii, chrześcijanie żyli od pierwszego wieku naszej ery. Do czasu powstania Państwa Islamskiego właśnie tam żyły społeczności na co dzień władające językiem, którym posługiwał się Jezus Chrystus - aramejskim. Choć przez wieki chrześcijanie na tych terenach cierpieli z powodu czystek islamskich, które rozpoczęły się jeszcze za życia proroka Mahometa, do końca XX wieku ich liczbę na terenie dawnej Mezopotamii można było określać w milionach. Gdy w 2003 roku do Iraku wkraczali Amerykanie, żyło tam przeszło 2 miliony chrześcijan. Byli szanowaną i nieszykanowaną grupą społeczną. Stanowili warstwę wykształconą, byli bliskowschodnią inteligencją. 12 lat temu system, w którym żyli, uległ zachwianiu. Niepokoje i zmiany u szczytu władzy wywołane amerykańską interwencją zaburzyły dobre relacje pomiędzy muzułmanami a chrześcijanami. Były też początkiem chaosu, jaki swoje apogeum w Iraku przechodzi obecnie. Największy dramat chrześcijanie na Bliskim Wschodzie przeżywają jednak od czasu powstania tzw. Państwa Islamskiego (IS lub ISIS - z ang. Islamic State of Iraq and Syria), czyli kalifatu powołanego na terenach należących wcześniej do Syrii i Iraku. Rok po ogłoszeniu powstania IS na terenie Iraku żyje już tylko 200 tysięcy chrześcijan, a ich liczba regularnie maleje. Chrześcijanie jako „niewierni” są masowo zabijani przez bojowników ISIS. Ci, którzy uszli z życiem, musieli uciekać ze swoich domów, pozostawiając za sobą cały dobytek i dotychczasowe życie. W niniejszym artykule postaram się nakreślić sytuację chrześcijan na terenie Iraku i Syrii, próbując odpowiedzieć na pytanie, czy działania Państwa Islamskiego wobec wyznawców religii chrześcijańskiej są prześladowaniem, czy też, w świetle obowiązujących międzynarodowych konwencji - ludobójstwem. W celu uzyskania odpowiedzi na zadane pytania posłużę się literaturą przedmiotu, ale i wywiadami, które przeprowadziłam z ekspertami, mieszkańcami Bliskiego Wschodu, a także z uchodźcami irackimi. Badanie tematu 
tak aktualnego implikuje korzystanie w dużej mierze $\mathrm{z}$ artykułów prasowych, również ze względu na ograniczoną liczbę publikacji, które do tej pory ukazały się na temat prześladowań wobec chrześcijan na terenie Bliskiego Wschodu. Artykuł, ze względu na obszerność tematu, skupia się na chrześcijanach zamieszkujących terytorium Iraku i Syrii, nie można jednak w tym kontekście zapominać o zbrodniach dokonywanych przez dżihadystów na innych terenach ich działań, jak choćby w Libii, gdzie jedną z dokonanych przez terrorystów masakr było ścięcie na plaży 21 koptyjskich chrześcijan z Egiptu.

\section{DZIESIĘĆ LAT PRZEŚLADOWAŃ}

Iraccy chrześcijanie dotkliwie odczuwali antagonizm i prześladowania od 2003 roku, czyli od czasu amerykańskiej inwazji na Irak. Za czasów Saddama Husseina mieli pełną swobodę wyznawania religii, a każda forma ekstremizmu islamskiego była przez władze surowo karana. Trzy lata po obaleniu dyktatora, w 2006 roku, UNHCR - agenda ONZ ds. uchodźców podała, że asyryjscy chrześcijanie w Iraku, mimo iż stanowili tylko 5 proc. 26-milionowego kraju, byli jednocześnie największą grupą uchodźców z tego kraju. Aż 40 proc. uchodźców irackich stanowili wówczas chrześcijanie ${ }^{1}$. W 2003 roku wyznawców Chrystusa było blisko 1,5 miliona² ${ }^{2}$ choć należy podkreślić, że księża działający od lat na tych terenach mówią o 2 milionach chrześcijan, którzy zamieszkiwali wówczas Irak.

Pierwszy duży atak terrorystyczny na chrześcijańskie kościoły miał miejsce 1 sierpnia 2004 roku $^{3}$. W niedużych odstępach czasu zamachowcy zorganizowali ataki bombowe na 6 kościołów w Bagdadzie i Mosulu, w których zginęło 12 osób, 71 zostało rannych. Jak wyliczyła w 2008 roku Asyryjska Agencja Informacyjna, tylko przez 4 lata doszło do ataków na 59 kościołów irackich chrześcijan ${ }^{4}$. W 2008 roku arcybiskup Mosulu został porwany i zabity ${ }^{5}$. Do 2010 roku 40 z 65 kościołów w Bagdadzie co najmniej raz zostało zbombardowanych, od 2010 roku wokół niemal każdego kościoła chrześcijańskiego w Iraku zbudowano dodatkowy mur ochronny ${ }^{6}$. Wielu chrześcijan wciąż jednak pozostało w Iraku w nadziei, że trudny okres był momentem przejściowym i w kraju zapanuje spokój. Nadzieje na poprawę sytuacji pogrzebał atak na kościół Najświętszej Maryi Panny Nieustającej Pomocy w Bagdadzie. 31 października 2010 roku uzbrojeni

\footnotetext{
${ }^{1}$ M. A. Vu, Assyrian Christians „Most Vulnerable Population” in Iraq, „The Christian Post” 5.12.2006, http://www.christianpost.com/news/23863/\#eluXbbCmRV60KsTd.99 (7.07.2015).

${ }^{2}$ Według danych podawanych m.in. w „The New York Times”: http://www.nytimes.com/2010/11/02/ world/middleeast/02iraq.html?_r=2\&scp=3\&sq=anthony\%20shadid\&st=cse (7.07.2015).

${ }^{3}$ Leaders condemn Iraq church bombs, BBC, 2.08.2004, http://news.bbc.co.uk/2/hi/middle_east/3527032. $\operatorname{stm}(7.07 .2015)$.

${ }^{4}$ Church Bombings in Iraq Since 2004, Assyrian Int'l News Agency, http://sverigesradio.se/diverse/appdata/ isidor/files/83/6810.pdf (7.07.2015).

${ }^{5}$ K. Powers, A Global Slaughter of Christians, but America's Churches Stay Silent, „The Daily Beast” 27.09.2013, http://www.thedailybeast.com/articles/2013/09/27/a-global-slaughter-of-christians-but-america-schurches-stay-silent.html (7.07.2015).

${ }^{6}$ J. Moore, Iraq's quiet Christian genocide, Fox News, 16.12.2014, http://www.foxnews.com/opinion/ 2014/12/16/iraqs-quiet-christian-genocide.html (7.07.2015).
} 
terroryści wtargnęli do kościoła podczas sprawowania niedzielnej Eucharystii, biorąc ok. 300 wiernych i księży jako zakładników. Wkrótce otworzyli do nich ogień. Gdy do świątyni wtargnęly irackie oddziały antyterrorystyczne, sprawcy zamachu zdetonowali ładunki wybuchowe ${ }^{7}$. Zginęło 58 osób, dziesiątki zostało rannych - była to największa masakra dokonana nie tylko na chrześcijanach, ale w Iraku w ogóle od 2003 roku. „Przyszli zabić ducha Iraku. Przyszli zabić powód do życia, każde marzenie, które chciałbyś, aby się spełniło “8 - powiedział reporterowi „The New York Times'a” jeden z ocalonych zakładników. W zamachu zginęło m.in. dwóch księży odprawiających mszę. Jeden z nich został rozstrzelany, gdy błagał zamachowców, by nie strzelali do wiernych'. Ks. prof. UKSW dr hab. Waldemar Cisło, dyrektor polskiej sekcji organizacji Pomoc Kościołowi w Potrzebie od 4 lat przynajmniej raz w roku jest w Iraku. W rozmowie przeprowadzonej podczas badań nad artykułem powiedział:

Do 2010 roku ludzie mieli tam nadzieję, która się werbalizowała w ten sposób: żyjemy w kraju wojny, nie mamy leków, nie mamy szkoły, nie mamy poczucia bezpieczeństwa, ale powoli ta sytuacja się będzie stabilizować, będziemy jakoś żyć. W 2010 roku, kiedy w dużym zamachu w jednym z kościołów zginęło dwóch księży i rozstrzelano kilkadziesiąt osób, to podłamało czy zabrało im nadzieję. Dzisiaj widzimy, że ta sytuacja jest bardzo smutna dla chrześcijan w Iraku, bo sprawdzają się te słowa powiedziane w 2010 roku - odebrano nam nadzieję tym zamachem. I oni uciekają, zresztą nie ma się co dziwić, liczby są brutalne. W 2003 roku mieliśmy ok. półtora miliona chrześcijan, dzisiaj niektórzy mówią o 100 tysiącach, niektórzy mówią o 200 tysiącach na terenie Iraku i to głównie skoncentrowanych w okolicach Irbilu i na terenie Kurdystanu. Ale myślę, że trzeba jednak podawać te liczby zaniżone, czyli ok. 100 tysięcy i ta liczba się ciągle zmniejsza ${ }^{10}$.

Na pół roku przed powstaniem Państwa Islamskiego podczas spotkania papieża Franciszka z przedstawicielami Kościołów wschodnich w dniach 19-22 listopada 2013 roku ojciec święty zaznaczył: „Wielki niepokój budzą warunki życia chrześcijan, którzy w wielu częściach Bliskiego Wschodu doznają w sposób szczególnie dotkliwy konsekwencji trwających tam napięć i konfliktów. Syria, Irak, Egipt i inne tereny Ziemi Świętej nieraz opływają łzami. Biskup Rzymu nie zazna spokoju, dopóki będą ludzie jakiejkolwiek religii, których godność się znieważa, których pozbawia się tego, co konieczne do życia, okrada z przyszłości, zmusza, by byli wygnańcami i uchodźcami. Dziś razem z pasterzami Kościołów Wschodu apelujemy, aby respektowano prawo wszystkich do godnego życia i swobodnego wyznawania wiary. Nie możemy pogodzić się z myślą, że Bliski Wschód pozostanie bez chrześcijan, którzy od dwóch tysięcy lat wyznają tam imię Jezusa, włączeni jako pełnoprawni obywatele w życie społeczne, kulturalne i religijne narodów, do których należą" ${ }^{\prime 1}$. Zaledwie pół roku później sytuacja chrześcijan na Bliskim Wschodzie uległa zdecydowanemu pogorszeniu, a nieliczna już grupa

${ }^{7}$ A. Shadid, Church Attack Seen as Strike at Iraq's Core, ,"The New York Times” 1.11.2010, http://www.nytimes.com/2010/11/02/world/middleeast/02iraq.html?_r=2\&scp=3\&sq=anthony\%20shadid\&st=cse (7.07.2015).

${ }^{8}$ A. Shadid, Church Attack Seen as Strike at Iraq's Core, dz. cyt.

${ }^{9}$ A. Shadid, Church Attack Seen as Strike at Iraq's Core, dz. cyt.

${ }^{10}$ Rozmowa z ks. prof. UKSW dr hab. Waldemarem Cisłą, Warszawa, 22.04.2015.

${ }^{11}$ Bliski Wschód pozostanie bez chrześcijan, „Gość Niedzielny” 23.11.2013, http://gosc.pl/doc/1787870. Bliski-Wschod-pozostanie-bez-chrzescijan (9.07.2015). 
wyznawców Chrystusa na terenach jeszcze niezajętych przez Państwo Islamskie została pozbawiona jakichkolwiek przywilejów społecznych, żyjąc w warunkach skrajnego wyczerpania fizycznego i psychicznego.

\section{ISLAM, PODATEK LUB ŚMIERĆ}

30 czerwca 2014 roku islamiści ogłosili powstanie kalifatu ${ }^{12}$, uznając ten dzień za oficjalnie kładący kres brytyjsko-francuskim uzgodnieniom mapy Bliskiego Wschodu po pierwszej wojnie światowej (porozumieniu Sykes’a-Pivota). W jednym z filmów, które zostały opublikowane tego dnia, bojownik Państwa Islamskiego ogłosił, że „nie ma na świecie armii, która mogłaby oprzeć się żołnierzom Islamu” ${ }^{13}$. Świat w niedługim czasie miał przekonać się, że terror przedstawicieli Państwa Islamskiego nie będzie opierał się w głównej mierze na walce z konkretną armią, ale na eksterminacji ludności Bliskiego Wschodu - wszystkich, którzy nie są sunnickimi wyznawcami religii islamskiej. Najdotkliwiej i najszybciej okrucieństwo ubranych na czarno bojówek IS mieli poznać zamieszkujący Irak i Syrię chrześcijanie.

Niemal natychmiast po zajęciu pierwszych miast - między innymi syryjskiej Raqqi, która stała się stolicą Państwa Islamskiego, i jednego z kluczowych irackich miast, Mosulu - rozpoczęła się masowa eksterminacja chrześcijan na tych terenach. Domy wyznawców Chrystusa jednej nocy zostały oznaczone arabskim odpowiednikiem litery „N”- co oznaczało „Nazarejczyka“. Chrześcijanie zostali postawieni przed wyborem jednej z trzech opcji: przejścia na Islam, zapłacenia podatku dla niewiernych (jizya) lub - wobec odmowy spełnienia jednego z dwóch wymienionych warunków - śmierci. Uczestniczący w pielgrzymce do Lourdes młodzi chrześcijanie z Iraku potwierdzili, że także ich rodziny dostały podobną listę wyboru: „Kiedy Państwo Islamskie zdobywało terytorium Niniwy, w której leży Mosul, przyszli do nas ok. 10:30 w nocy, to była środa. Wysłali list, w którym było napisane: albo, jako niewierny, zapłacisz podatek, albo opuścisz swój dom, albo cię zabijemy. Jeśli zdecydujesz się opuścić dom, masz zostawić w nim wszystko - złoto, ubrania, samochody, wszystko, co posiadasz, jedyne, co możesz wziąć ze sobą, to to, co nosisz na sobie. Wzięli nasze pieniądze, nasze paszporty, dowody osobiste, wzięli nasze domy. Każdy chrześcijański dom oznaczyli literą «N» - «Nazarejczycy», co u nas oznacza chrześcijan"14. Abdul, którego imię zostało zmienione, gdyż wciąż, mieszkając już poza Irakiem, obawiał się o swoje życie, w dniu otrzymania listu od ISIS napisał ostatni test podczas studiów z dziedziny marketingu na Uniwersytecie w Mosulu. Miesiąc później miał otrzymać dyplom magistra. Gdy wraz z rodziną uciekł z miasta, nie mógł wziąć ze sobą żadnego dowodu, że kiedykolwiek studiował. Będąc uchodźcą we Francji, nie może udowodnić, że ukończył szkołę podstawową.

${ }^{12}$ ISIS announces islamic caliphate in area straddling Iraq and Syria, 30.06.2014, http://www.theguardian. com/world/2014/jun/30/isis-announces-islamic-caliphate-iraq-syria (6.07.2015).

${ }^{13}$ ISIS announces islamic caliphate..., dz. cyt.

${ }^{14}$ Rozmowa z grupą irackich uchodźców mieszkających tymczasowo we Francji, Lourdes, 4.05.2015. 
Ksiądz Douglas Bazi w swoim kościele w Irbilu, stolicy irackiego Kurdystanu, dał schronienie 140 rodzinom - niemal wszyscy mieszkali wcześniej w Mosulu i okolicach. „Nie lubię nazywać ludzi tu mieszkających uchodźcami, nazywam ich kuzynami. A mój obóz nazywam po prostu centrum. Wszyscy ludzie mieszkający w moim centrum mieli domy, mieli samochody i pracę ${ }^{\prime 15}$. Uchodźcy mieszkający w ogrodach kościoła ks. Douglasa mieszkają w metalowych barakach. Latem temperatura dochodzi tu do 50 stopni. W jednym baraku, w którym nie ma podziału na domowe pomieszczenia, mieszkają całe rodziny. „Dziwię się że oni jeszcze nie zwariowali, to już rok od kiedy te rodziny żyją wszyscy razem w tych kontenerach, w rozmiarze 3 na 6 metrów, to nie jest łatwe - dzielą nawet prysznic, tu nie ma życia prywatnego. Wielu ludzi mówi mi, że nie żyją już jak małżeństwo, ale jak rodzeństwo, tu nie ma miejsca na prywatność" ${ }^{16}$. Ks. Douglas Bazi, zanim trafił do Irbilu, służył w Bagdadzie, gdzie dwukrotnie przeżył ataki na swoją parafię. Pierwszy atak był atakiem bombowym, drugi - strzelaniną między szyickimi a sunnickimi bojówkami. „Zostałem postrzelony z AK-47 w lewą nogę, porwano mnie i przetrzymywano przez 9 dni. To było bardzo trudne 9 dni, wciąż nie mogę o tym zapomnieć, traktowali mnie jako «niewiernego» bardzo źle, straciłem wszystkie zęby, złamali mi kręgosłup i uwolnili dopiero, gdy kościół zapłacił okup. Pozostałem jednak w Bagdadzie aż do 2014 roku. Teraz w Irbilu czuję się, jakbym z powrotem był w Bagdadzie, tu jest taka sama sytuacja"17.

\section{BARBARZYŃSKI MARSZ BOJOWNIKÓW ISIS}

Barbarzyństwo bojowników państwa islamskiego wykracza poza jakiekolwiek normy międzynarodowe. Korzeni metod stosowanych przez żołnierzy ISIS można szukać w czasach narodzenia religii islamskiej. Reportażysta Witold Gadowski podczas przygotowywania filmu dokumentalnego o Państwie Islamskim spotkał się z bojownikami ISIS. Podczas rozmowy przeprowadzonej na potrzeby niniejszego artykułu tłumaczył, że niezrozumiały w Zachodnim świecie poziom barbarzyństwa „wynika z zasad wahabityzmu, czyli jednej z najbardziej radykalnych interpretacji Koranu, wynika z prawa szariatu i wynika z pewnych interpretacji kodeksu Hammurabiego, którą przedstawia szariat chodzi o to, że odpłata za zbrodnie musi być ekwiwalentna. Dlatego jordański lotnik został spalony w klatce - wcześniej ludzie ISIS twierdzili, że jordańscy piloci, w tym on, zrzucali napalm na ich pozycje - więc został adekwatnie potraktowany, czyli spalony. Jeżeli ktoś wyłupi oko, ma mieć wyłupione oko, jeśli ukradnie, ma mieć obciętą rękę, jeśli jest homoseksualistą, ma być zrzucony z dachu. To okrucieństwo, które z naszego punktu widzenia jest bardzo duże, dla nich jest normą, dlatego że ISIS w dużej mierze tworzą plemiona beduińskie, gdzie sprawiedliwość wymierzana jest od wieków w ten sposób” ${ }^{38}$.

${ }^{15}$ Rozmowa przez Skype z ks. Douglasem Bazi, opiekunem diecezji w Irbilu, prowadzącym centum uchodźców i szkołę dla ich dzieci, 5.05.2015.

${ }^{16}$ Rozmowa przez Skype z ks. Douglasem Bazi...

${ }^{17}$ Rozmowa przez Skype z ks. Douglasem Bazi...

${ }^{18}$ Rozmowa z reportażystą Witoldem Gadowskim, Kraków, 13.06.2015. 
Informacje o okrucieństwie bojowników islamskich przekazywane są w czasach globalizacji za pomocą środków masowego przekazu, także za pomocą nowych mediów. Z internetowych przekaźników korzystają przede wszystkim sami oprawcy, bogato dokumentując popełniane przez siebie zbrodnie. Terrorystyczna ideologia zastraszenia kolejnych potencjalnych ofiar islamistów szerzona jest wszelkimi nowoczesnymi kanałami internetowymi. Państwo Islamskie rozpowszechnia chociażby filmy z egzekucji, takich jak publiczne ścięcia, palenie czy topienie żywcem swoich ofiar. Terror stosowany przez Państwo Islamskie jest zagadnieniem tak szerokim, że w krótkim opracowaniu nie ma miejsca na szczegółowy jego opis, zatem skupię się tu głównie na przypadkach prześladowania chrześcijan, nie mogąc nie wspomnieć o innych iracko-syryjskich mniejszościach religijnych.

Podczas przesłuchania w podlegającym Departamentowi Stanu USA Podkomitecie ds. międzynarodowych: globalnego zdrowia, praw człowieka i organizacji międzynarodowych na Bliskim Wschodzie Tom Malinowski, podsekretarz stanu USA ds. demokracji, praw człowieka i pracy, powiedział we wrześniu 2014 roku: „Jedną z jasnych ambicji ISIL ${ }^{19}$ jest destrukcja bogatego dziedzictwa religijnego Iraku i jego etnicznej dywersyfikacji, a także absolutne uciemiężenie ludzi znajdujących się w ich zasięgu"20.

Marsz bojowników ISIS rozpoczął się od Mosulu, który bojownicy zdobyli 9 czerwca 2014 roku $^{21}$. Tego samego dnia mieszkańcy zaczęli masową ucieczkę, obawiając się śmierci z rąk fanatycznych bojowników. Na efekty zapowiedzi ISIS nie trzeba było długo czekać. Exodus chrześcijan, jazydów i szyitów poprzedzony został masowymi egzekucjami, w tym za pomocą publicznego ścięcia. Nie tylko podczas zajmowania Mosulu, ale i innych miast bojownicy zmuszali ludzi, grożąc zabiciem ich najbliższych, do konwersji na islam; torturowali, gwałcili, kobiety i dzieci były używane jako żywe tarcze, ludzie byli paleni lub grzebani żywcem ${ }^{22}$. „Kobiety i dziewczynki tak młode, 12-13-letnie, były przetrzymywane, by później zostać sprzedanymi na targu jako niewolnice seksualne, albo zmuszane do małżeństwa z wojownikami ISIL"23. Ten sam scenariusz wcześniej był realizowany na terenach zajętych przez ISIS w Syrii, w tym w uważanej za stolicę Państwa Islamskiego Rakce. Według amerykańskiego Departamentu Stanu niemal cała społeczność chrześcijańska, jak i społeczność jazydów została przesiedlona ${ }^{24}$. „Otrzymaliśmy raporty mówiące o pięciu niepełnosprawnych chrześcijanach, którzy nie mogli samodzielnie uciec przez swoją chorobę, zostali doprowadzeni do meczetu i zmuszeni do przyjęcia islamu" ${ }^{25}$. W Mosulu czy Karakoszu - miastach, gdzie znajdowały się duże

${ }^{19}$ Islamic State of Iraq and the Levant - pierwotna nazwa organizacji przed ogłoszeniem państwa islamskiego, długo używana formalnie przez rząd Stanów Zjednoczonych, który nie uznawał państwa ISIS i określał terrorystów za pomocą nazwy własnej organizacji.

${ }^{20}$ Testimony: Tom Malinowski, Assistant Secretary, Bureau of Democracy, Human Rights, and Labor

As-Prepared Opening Statement, House Foreign Affairs Subcommittees on Africa, Global Health, Global Human Rights and International Organizations and the Middle East and North Africa, Washington, DC, September 10, 2014, http://www.state.gov/j/drl/rls/rm/2014/231483.htm (7.07.2015).

${ }^{21}$ M. Chulov, Isis insurgents seize control of Iraqi city of Mosul, „The Guardian” 10.06.2014, http://www. theguardian.com/world/2014/jun/10/iraq-sunni-insurgents-islamic-militants-seize-control-mosul (7.07.2015).

${ }^{22}$ Cyt. za: Testimony: Tom Malinowski, dz.cyt.

${ }^{23}$ Testimony: Tom Malinowski, dz. cyt.

${ }^{24}$ Testimony: Tom Malinowski, dz. cyt.

25 Testimony: Tom Malinowski, dz. cyt. 
dzielnice chrześcijańskie - bojownicy rozstrzeliwali całe rodziny, znane są także przypadki zabójstw biegnących ulicą kilkuletnich dzieci.

Kolejna ofensywa krwawego marszu islamistów nastąpiła na początku sierpnia 2014 roku. Wtedy ISIS zaatakował obszar Niniwy, zamieszkiwany przez wielu chrześcijan. Wtedy także rozpoczął się dramat ludności jazydów, którzy uciekając przed siłami ISIL, zostali zapędzeni na górę Sinjar, którą otaczali terroryści. Jazydzi zostali odcięci od źródeł pożywienia i wody. W połowie sierpnia 2014 roku specjalny przedstawiciel ONZ ostrzegał, że ludobójstwo jazydów uwięzionych na górze Sinjar „może wydarzyć się w ciągu kilku godzin lub dni”26. Jazydzi, którym udało się przetrwać, byli świadkami niewyobrażalnego okrucieństwa bojowników ISIS. Jedna z kobiet relacjonowała amerykańskiej telewizji chrześcijańskiej CBN: „Kiedy nadeszli terroryści z ISIS, łapali ludzi, porywali piękne dziewczęta i je zabierali. My uciekliśmmy"27. Kobieta opowiadała, że jej syn wrócił do wioski po zapasy żywności. Bojownicy ISIS schwytali go, zastrzelili, wyłupili oczy i odcięli głowę. Pochował go przyjaciel. Amerykańscy dyplomaci i przedstawiciele środowiska jazydów w USA świadczyli o przypadkach masowych gwałtów na kobietach i o dzieciach umierających z odwodnienia podczas marszu na górę Sinjar. Jednym z przykładów okrucieństwa jest eksterminacja całej jazydzkiej wioski Kocho - po kilku dniach przetrzymywania jej mieszkańców na terenie szkoły i ostatecznej odmowy konwersji na Islam, mężczyzn wywieziono poza wioskę i zabito strzałem w tył głowy, a kobiety i dzieci zabrano na tereny zajęte przez Państwo Islamskie ${ }^{28}$. Według relacji amerykańskiego dyplomaty Toma Malinowskiego kobiety i dzieci z Kocho podzieliły los tysięcy jazydów: „Według naszych raportów setki rodzin zostało zmuszonych do konwersji na islam, w wielu przypadkach poprzedzonych okrutnymi przypadkami bicia dzieci na oczach matek tak długo, że kobiety, nie mogąc dłużej znieść tego widoku, przechodziły na islam [...] Regularnie otrzymujemy raporty o kobietach dystrybuowanych do bojowników ISIS jako łupy wojenne, sprzedawanych na targach jako seksualne niewolnice lub przetrzymywanych w domach w małych grupach, gdzie są codziennie gwałcone przez innych bojowników ISIS"29. Podobny los spotkał najprawdopodobniej ponad 100 kobiet - chrześcijanek z miasta Karakosz. Tom Malinowski w swoim wstrząsającym raporcie mówił także o przypadku 3-letniej dziewczynki odebranej rodzicom - chrześcijanom podczas ucieczki. Rodzice zostali zmuszeni do odejścia, podczas gdy dziecko na ich oczach zostało zabrane przez bojowników. Nie jest to przypadek odosobniony. Johnnie Moore, amerykański pisarz doświadczony w działalności humanitarnej na całym świecie, opisuje w swojej książce Pokonać ISIS przypadek 3-letniej Christiny. Rodzice dziewczynki wraz z córką przebywali w swoim domu w Karakosz, kiedy ISIS wkroczyło do miasta. Rodzina od pokoleń była chrześcijańska. ISIS, rutynowo, zabrało

${ }^{26}$ J. Cusick, Iraq crisis: Yazidis refugees trapped on Mount Sinjar are facing imminent "genocide” from IS militants, UN warns, „The Independent” 12.08.2014, http://www.independent.co.uk/news/world/middle-east/iraq-crisis-un-warns-yazidis-refugees-trapped-on-mount-sinjar-are-facing-imminent-genocide-from-is-militants-9665003.html (8.07.2015).

${ }^{27}$ C. Mitchel, For Yazidis, Christians: „They Cut Us Like Sheep”, CBN News, 26.08.2014, http://www.cbn. com/cbnnews/world/2014/August/Fleeing-Yazidis-Face-Uncertain-Future/ (8.07.2015).

${ }^{28}$ Iraq crisis: Yazidi villagers „massacred” by IS, BBC News, 16.08.2014, http://www.bbc.com/news/world-middle-east-28814633 (8.07.2015).

${ }^{29}$ Testimony: Tom Malinowski, dz. cyt. 
im w pierwszej kolejności kosztowności. Nakazano także rodzinie wsiąść do autobusu. Rodziców wysadzono na pustyni i na ich oczach zabrano ich trzyletnią córkę. „Błagałam ich, by ją mi oddali. Błagałam wielokrotnie, ale oni nie posłuchali”30 - relacjonowała autorowi książki Aida, matka dziewczynki. Kobieta zaczęła pościg za autobusem, jeden z bojowników rzucił ją jednak na tył pojazdu i zaznaczył, że litują się nad nią, że jeszcze nie została zabita. 3-letnia Christina została porwana przez bojowników ISIS. Rodzice dziewczynki bezskutecznie próbowali odzyskać, a nawet wykupić córkę. Wiedzą jedynie, że przebywa w siedzibie jednego z wysoko postawionych emirów Państwa Islamskiego. „Jako matka przechodzę przez tortury. Ciągle o niej myślę. Nie mogę jeść ani spać. Widzę ją w moich snach"31 . Jej przypadek to jeden z setek dramatów rodzinnych rozgrywających się na terenach zajętych przez Państwo Islamskie.

Bojownicy Państwa Islamskiego wykorzystują cierpienie dzieci, by zmusić rodziców do konwersji na islam. Ks. Waldemar Cisło podał przykład matki, która by ratować swoje nastoletnie córki, wyrzekła się Chrystusa:

„Kiedy byłem [w Iraku - przyp. red.] w październiku to jedna z kobiet potrzebowała się przed kimś usprawiedliwić i powiedzieć to, co nosiła w sobie. Mieszkała w jednym z baraków, który my, Polacy, finansowaliśmy, i pokazywała mi trójkę swoich córek. Powiedziała: «proszę księdza, ja się wyrzekłam Chrystusa oficjalnie, ale w sercu zostałam chrześcijanką. Miałam tę trójkę swoich córek przy sobie i wiedziałam, że jeśli się nie wyrzeknę, to one będą na moich oczach gwałcone i będą męczone, żeby tylko wyrzec się Chrystusa». Powiedziałem jej «Nikt nie będzie pani osądzał, bo nikt nie wie, jak by się zachował w takiej sytuacji wojny». To są sytuacje nieporównywalne, nie do opisania, poza tym ratując te trzy dziewczynki, miała do tego prawo - dorosły człowiek może o sobie decydować, ale te biedne dzieci co są temu winne, zresztą one i tak wystarczająco dużo tej wojny widziały"32.

Najnowszy raport Syryjskiego Obserwatorium Praw Człowieka mówi o 3027 egzekucjach dokonanych przez ISIS w ciągu roku od ogłoszenia powstania kalifatu ${ }^{33}$. Wśród zabitych znalazło się 74 dzieci i 86 kobiet. Tylko w czerwcu ISIS ukrzyżowało dwoje dzieci za nieprzestrzeganie ścisłego postu w trakcie świętego miesiąca Ramadan ${ }^{34}$. Już wcześniej świat obiegały barbarzyńskie zdjęcia, na których widać było ścięte ludzkie głowy zatknięte na palach w miejskich parkach, w tym głowy dzieci.

\section{BLISKI WSCHÓD BEZ CHRZEŚCIJAN?}

W liście apostolskim wprowadzającym chrześcijaństwo w trzecie tysiąclecie Tertio millenio adveniente św. Jan Paweł II pisał: „Kościół pierwszego tysiąclecia zrodził się

${ }^{30}$ J. Moore, Defying ISIS, Nashville 2015, s. 33, kindle edition.

${ }^{31}$ J. Moore, Defying ISIS, dz. cyt., s. 33.

${ }^{32}$ Rozmowa z ks. Waldemarem Cisłą.

${ }^{33}$ A. Sehmer, Isis executed scores of children in a year of its caliphate, "The Independent" 29.06.2015, http://www.independent.co.uk/news/world/middle-east/isis-executed-scores-of-children-in-a-year-of-its-caliphate-10352256.html (8.07.2015).

${ }^{34}$ A. Sehmer, Isis executed scores of children..., dz. cyt. 
z krwi męczenników: Sanguis martyrum - semen christianorum. Historyczne wydarzenia związane z postacią Konstantyna Wielkiego nigdy nie potrafilyby zapewnić takiego rozwoju Kościoła, jakiego byliśmy świadkami w pierwszym tysiącleciu, gdyby nie ów posiew męczeński oraz wielkie dziedzictwo świętości pierwszych pokoleń chrześcijan. U kresu drugiego tysiąclecia Kościół znowu stał się Kościołem męczenników. Prześladowania ludzi wierzących - kapłanów, zakonników i świeckich - zaowocowały wielkim posiewem męczenników w różnych częściach świata. Świadectwo dawane Chrystusowi aż do przelania krwi stało się wspólnym dziedzictwem zarówno katolików, jak prawosławnych, anglikanów i protestantów [...]" ${ }^{\prime 35}$. Słowa Jana Pawła II brzmią dziś szczególnie aktualnie. „Jedyną winą, jaką nosimy w sobie, jest nasza wiara” - powiedział w rozmowie przeprowadzonej na potrzeby artykułu ks. Douglas Bazi. Szacuje się, że ginących za wiarę chrześcijan jest na świecie 170 tysięcy rocznie. Ks. Waldemar Cisło dodał: „[... ] nie chodzi o liczbę, ale o fakt, że świat, który dzisiaj mówi o podstawowych prawach człowieka, o godności, o wolności człowieka, nie respektuje podstawowego prawa, jakim jest prawo do swobody wyznawania wybranej przez nas religii. Niemniej jednak w przybliżeniu można powiedzieć, że przez długi czas utrzymywała się ta liczba 170 tysięcy chrześcijan zamordowanych za wiarę. Ostatnie dane podane przez profesorów włoskich to 105 tysięcy. Czyli wychodzi na to, że co 5 minut na świecie ginie ktoś za to, że jest wyznawcą Chrystusa. Zmienia się geografia, myślę, że skala się nie tyle zmienia, co się zmienia geografia"36. Jednym z terytoriów, gdzie dochodzi dziś do najbardziej brutalnych mordów na chrześcijanach, jest Bliski Wschód, a szczególnie teren Iraku i Syrii.

Biorąc pod uwagę błyskawiczny przyrost liczby chrześcijańskich uchodźców i liczby zabitych, można przypuszczać, że w niedługim czasie tereny te zostaną całkowicie oczyszczone z ludności chrześcijańskiej, m.in. przez działania Państwa Islamskiego.

„Bliski Wschód bez chrześcijan już nie będzie tym samym Bliskim Wschodem”37 pisał papież Benedykt XVI, podkreślając, że „Bliski Wschód zajmuje szczególne miejsce w sercach wszystkich chrześcijan, ponieważ właśnie tam Bóg pierwszy dał się poznać naszym ojcom w wierze" ${ }^{\text {38 }}$.

Reporterka BBC Jane Corbin w kwietniu dotarła do jednego z najstarszych monastyrów chrześcijańskich w północnym Iraku - zakonu św. Mateusza na górze Alfaf. W czasach gdy oficjalną religią Cesarstwa Rzymskiego było chrześcijaństwo, żyło tam 6 tysięcy mnichów. Teraz mieszka tam 6 mnichów i kilkanaście chrześcijańskich rodzin, którym udzielili schronienia. Pustelnia znajduje się w samym centrum frontu z ISIS ${ }^{39}$. Chrześcijanie, których reporterka spotkała w Iraku, powiedzieli, że spodziewają się, że za 5 lat na tych terenach już ich nie będzie. Jedna z kobiet mieszkających z rodziną w monastyrze powiedziała Corbin: „Nie możemy wrócić do Mosulu ze strachu przez śmiercią, porwaniem czy grabieżą”. Inna dodała: „Nie możemy wrócić do Mosulu, bo

\footnotetext{
${ }^{35}$ Jan Paweł II, List apost. Tertio Millenio Adveniente, cz. IV - przygotowanie bezpośrednie, http://www. opoka.org.pl/biblioteka/W/WP/jan_pawel_ii/listy/tertio.html\# (7.07.2015).

${ }^{36}$ Rozmowa $\mathrm{z}$ ks. dr hab. Waldemarem Cisłą.

${ }^{37}$ Benedykt XVI, adhort. Ecclesia in Medio Oriente, 31, cyt. za: Prześladowani i zapomniani. Raport o prześladowaniach chrześcijan w latach 2011-2012, red. W. Cisło, Warszawa 2013, s. 9.

${ }^{38}$ Benedykt XVI, adhort. Ecclesia in Medio Oriente, 31.

${ }^{39}$ J. Corbin, Could Christianity be driven from Middle East?, BBC News, 15.04.2015, http://www.bbc.com/ news/world-middle-east-32287806 (8.07.2015).
} 
nic tam nie mamy”. Takie historie potwierdził ks. Waldemar Cisło, zaznaczając, że cała własność należąca do chrześcijan została zrabowana przez ISIS: „Chrześcijanie na Bliskim Wschodzie są albo bardzo dobrymi biznesmenami, albo są elitą intelektualną - to są lekarze, często profesorowie, oni musieli sobie znaleźć taki sposób na przeżycie mniejszości w tej większości muzułmańskiej. Jedna pani opowiadała mi, że w Mosulu zostawiła 600-metrowy dom, rok wcześniej wykończony, ostatnie meble przewiezione - mówi mi - ja dzisiaj proszę księdza mieszkam w baraku" ${ }^{40}$.

Po 1400 latach obecności chrześcijan w Mosulu w mieście nie ma obecnie odprawianej ani jednej mszy świętej. Jak powiedział ks. Cisło - „taki komunikat poszedł do ojca świętego". Jeszcze w 2012 roku chaldejskokatolicki arcybiskup Mosulu Amel Nona mówił, że chrześcijaństwo w Iraku może stać się „zjawiskiem marginalnym”, dodając: „Już teraz nasz wpływ na irackie społeczeństwo dramatycznie osłabł, a uchodźcy nie powrócą przecież do naszego kraju" ${ }^{41}$. Arcypiskup Nona, po roku tymczasowego mieszkania w Irbilu, w 2015 roku został przeniesiony przez patriarchę Iraku do Australii - tam gdzie obecnie przebywają uchodźcy z jego archidiecezji, co w obliczu jego wcześniejszych słów stało się wymowne i symboliczne.

Irakijczycy otwarcie mówią o tym, że ich marzeniem jest wyjechać z kraju. Sytuacja jest podobna w chrześcijańskich miastach syryjskich. Z bastionu chrześcijan - miasta Maaloula w 2013 roku uciekło 3000 chrześcijan. W tym ludzie mówiący po aramejsku. Była to jedna $z$ kilku zaledwie miejscowości na świecie, gdzie język ten można było usłyszeć na co dzieńn ${ }^{42}$. Antoinette, mieszkanka miasta, powiedziała reporterce BBC: „Maaloula jest w moim sercu, nie mogę jej opuścić bo jeśli nie będzie chrześcijan w Maaloula, myślę, że nie będzie ich w całej Syrii”43. Ks. Douglas Bazi, który w swoim kościele w Irbilu daje schronienie niemal 140 chrześcijańskim rodzinom, nie ma nadziei, że chrześcijanie pozostaną w Iraku: „Irakijczycy żyjący poza Irakiem zwykli mówić: bądźcie dzielni, zostańcie, nie opuszczajcie Bliskiego Wschodu. I jestem dumny, bo żyję tu z moimi ludźmi po tym wszystkim co przeszliśmy, kocham mój kraj. Ale z dnia na dzień wierzę coraz mocniej w to, że mój kraj nie jest dumny ze mnie, że zostałem, więc powtarzam ciągle - otwórzcie bramy swoich krajów dla moich ludzi. Jaki to ma sens, by owce żyły pośród wilków”44. Ksiądz Bazi dodał, że w Iraku jego społeczność jest póki co bezpieczna, ale ludzie są w niebezpieczeństwie. „Poza Irakiem społeczność ulegnie rozpadowi, ale ludzie będą bezpieczni. Ludzie mówią, jaka szkoda - Irak bez chrześcijan, Bliski Wschód bez chrześcijaństwa. Ale ja mówię jak matka - co jest ważniejsze Bliski Wschód czy ludzie? To jest wyłącznie strata dla Bliskiego Wschodu - nie mieć tu chrześcijan. Nie wińcie za to moich ludzi, to nie jest nasz wybór, jesteśmy zmuszani do życia na tym poziomie" 45 .

Eksterminacja chrześcijan na terenie dawnej Mezopotamii wiąże się z nieodwracalnymi zmianami o charakterze etnicznym. Wspomniane miasto Maaloula w Syrii jest jednym z kilku na świecie (i kilku na terenie Iraku i Syrii), gdzie grupa Aramejczyków

\footnotetext{
${ }^{40}$ Rozmowa z ks. Waldemarem Cisłą.

${ }^{41}$ Prześladowani i zapomniani..., dz. cyt., s. 106.

${ }^{42}$ J. Corbin, Could Christianity be driven from Middle East?, dz. cyt.

${ }^{43}$ J. Corbin, Could Christianity be driven from Middle East?, dz. cyt.

${ }^{44}$ Rozmowa przez Skype z ks. Douglasem Bazi.

${ }^{45}$ Rozmowa przez Skype z ks. Douglasem Bazi.
} 
mówiła na co dzień dialektem, którym posługiwał się Jezus Chrystus ${ }^{46}$. Nie chodzi jednak tylko o zachowanie ciągłości językowej ze względu na najbardziej znanego człowieka, który go używał. 3000 lat temu język aramejski był ówczesnym lingua franca, językiem używanym w handlu, dyplomacji i na co dzień. Tylko języki chiński, hebrajski i grecki mogą pochwalić się tak daleko sięgającym wstecz dziedzictwem ${ }^{47}$. Jedno z najważniejszych zdań dla chrześcijan wypowiedzianych przez Chrystusa na krzyżu: Eli, Eli, lama sabachthani? („Boże mój, Boże, czemuś mnie opuścił?”) to najbardziej bodaj znany w świecie przykład języka aramejskiego. Dziś, w obliczu dużego rozproszenia rodzin mówiących w języku aramejskim, spowodowanego wojną domową w Syrii połączoną z atakami bojowników Państwa Islamskiego, możliwości przetrwania społeczności mówiących tym starożytnym dialektem maleją z dnia na dzień.

\section{LUdobójstwo}

Konwencja w sprawie zapobiegania i karania zbrodni ludobójstwa uchwalona przez Zgromadzenie Ogólne Narodów Zjednoczonych 9 grudnia 1948 roku - trzy lata po zakończeniu II wojny światowej - jako ludobójstwo określa „którykolwiek z następujących czynów, dokonany w zamiarze zniszczenia w całości lub części grup narodowych, etnicznych, rasowych lub religijnych, jako takich:

1. zabójstwo członków grupy,

2. spowodowanie poważnego uszkodzenia ciała lub rozstroju zdrowia psychicznego członków grupy,

3. rozmyślne stworzenie dla członków grupy warunków życia obliczonych na spowodowanie ich całkowitego lub częściowego zniszczenia fizycznego,

4. stosowanie środków, które mają na celu wstrzymanie urodzin w obrębie grupy

5. przymusowe przekazywanie dzieci członków grupy do innej grupy ${ }^{48}$.

Prześladowania chrześcijan i innych mniejszości religijnych w Iraku, których przykłady podano w artykule, dowodzą, że postępowanie Państwa Islamskiego spełnia znamiona zbrodni ludobójstwa wobec każdego z wymienionych punktów Konwencji. Chrześcijanie są regularnie i brutalnie masowo zabijani (ad. a), wielu z nich, w tym kobiety i dzieci, cierpi z powodu uszkodzeń ciała, gwałtów i okaleczeń. Przypomnieć należy, że według zasad wahabityzmu i prawa szariatu obowiązujących na terenie kalifatu islamskiego kary cielesne są powszechne i szeroko stosowane, kobiety zaś traktuje się przedmiotowo. Do „rozstroju zdrowia psychicznego członków grupy”, jak podaje Konwencja w Artykule II podpunkcie b, doprowadzają warunki bytowe chrześcijan, niepewność jutra związana choćby z grabieżą całości majątku. Islamiści rozmyślnie tworzą także warunki życia, prowadzące do całkowitego lub częściowego zniszczenia fizycznego mniejszości

\footnotetext{
${ }^{46}$ J. Corbin, Could Christianity be driven from Middle East?, dz. cyt.

${ }^{47}$ R. Perlin, Is the Islamic State Exterminating the Language of Jesus?, „Foreign Policy” 14.08.2014, http:// foreignpolicy.com/2014/08/14/is-the-islamic-state-exterminating-the-language-of-jesus/ (8.07.2015).

${ }^{48}$ Konwencja ws. zabobiegania i karania zbrodni ludobójstwa, New York, 9 grudnia 1948, http://www. hrweb.org/legal/genocide.html (8.07.2015).
} 
etnicznych. Tak było w przypadku jazydów, uwięzionych na górze Sinjar bez wody i żywności. Sukcesywna dyskryminacja chrześcijan poprzez brak pracy i środków do życia eliminuje te grupy całkowicie z terenów Iraku. ISIS stosuje także środki, które mają na celu wstrzymanie urodzin w obrębie grup mniejszości religijnych. Ludzie zmuszeni do mieszkania w barakach nie decydują się na powiększenie rodziny, bojąc się o byt swoich nienarodzonych dzieci.

Ksiądz Douglas Bazi otwarcie mówi także o psychicznej barierze dla prokreacji $\mathrm{w}$ warunkach wielopokoleniowego mieszkania pod jednym dachem w żelaznym baraku. Duchowny z troską relacjonował słowa jednego z mężczyzn mieszkających w jego obozie: „nasze żony stały się ponownie dziewicami” ${ }^{49}$. Opisywane w artykule przypadki porywania dzieci i odbierania ich chrześcijańskim rodzicom w celu przekazania w ręce społeczności islamskiej są najlepszym przykładem, że ludobójstwo odbywa się również na szczeblu „przymusowego przekazywania dzieci członków grupy do innej grupy”.

Ksiądz Bazi nie ma wątpliwości, że w Iraku mamy do czynienia z ludobójstwem: „Do ludobójstwa dochodzi przecież nie tylko wtedy, kiedy kogoś fizycznie zabijasz, ale kiedy stwarzasz warunki do eksterminacji danej grupy [...]. Atakują nas i zabijają, bo jesteśmy ostatnią wykształconą grupą w Iraku. Kiedy nas nie będzie - mogą zrobić z Irakiem, co im się podoba" ${ }^{50}$.

Również według ks. Waldemara Cisły kwestię chrześcijan w Iraku i Syrii należy nazwać ludobójstwem: „Tak, to jest czyszczenie tego terenu z chrześcijan i to jest ewidentne, to jest wymazywanie także materialnych znaków obecności" ${ }^{11}$.

W pierwotnym projekcie Konwencji ws. zapobiegania i karania zbrodni ludobójstwa czyny te miały być podzielone na trzy kategorie ${ }^{52}$ :

- ludobójstwo fizyczne polegające na ograniczeniu urodzin,

- ludobójstwo biologiczne, polegające na ograniczeniu urodzin,

- ludobójstwo kulturalne polegające na niszczeniu cech charakterystycznych danej grupy.

Choć kategorie te ostatecznie nie znalazły się w konwencji, ewidentnie jednak niszczenie dziedzictwa danej grupy, w tym przypadku religijnej, jest czynem noszącym znamiona ludobójstwa. Jednym z podstawowych praw człowieka jest prawo do swobody wyznania. Niszczenie spokoju psychicznego danej grupy poprzez akty terroru w świątyniach, dewastację emocjonalnych więzi w lokalnych społecznościach czy też niszczenie liczącego wiele tysięcy lat dziedzictwa kulturowego danej grupy etnicznej czy religijnej należy uznać za prowadzące do ludobójstwa. Mowa tu chociażby o dewastowaniu wszystkiego, co związane z chrześcijaństwem - od świątyń przez święte figury po monumentalne zabytki i ośrodki religijne, takie jak grób proroka Jonasza, wysadzony przez ISIS w powietrze 25 lipca 2014 roku. „To atak zarówno na Chrześcijan żyjących dziś w Iraku, jak też na bogate, a mało znane powszechnie chrześcijańskie dziedzictwo w regionie" ${ }^{53}$ - powiedzieli tego dnia na antenie CNN eksperci. Islamiści na drodze

\footnotetext{
${ }^{49}$ Rozmowa przez Skype z ks. Douglasem Bazi.

${ }^{50}$ Rozmowa przez Skype z ks. Douglasem Bazi.

${ }^{51}$ Rozmowa z ks. Waldemarem Cisłą.

52 Cyt. za: K. Kosińska, Polityczne i prawne regulacje dotyczące zbrodni ludobójstwa, Toruń 2008, s. 63.

${ }^{53}$ D. Ford, M. Tawfeeq, Extremists destroy Jonah's tomb, officials say, CNN, http://edition.cnn.com/2014/ 07/24/world/iraq-violence/ (8.07.2015).
} 
swojego barbarzyńskiego marszu od połowy lipca 2014 roku zniszczyli setki chrześcijańskich kościołów i szyickich meczetów ${ }^{54}$.

Działania noszące znamiona aktów ludobójczych to także uniemożliwianie kształcenia dzieciom chrześcijańskim, a chrześcijanie tradycyjnie stanowili dobrze wykształconą i inteligencką klasę społeczną w Iraku. Podczas podróży do Iraku abp. Stanisława Gądeckiego i ks. Waldemara Cisły w lutym 2015 roku Irakijczycy prosili przede wszystkim o zapewnienie kontynuacji edukacji ich dzieciom: „pierwsze, o co nas prosili, to żeby te dzieci nie pozostawały bez szkoły. Wybudowaliśmy dwie duże szkoły z kontenerów, tam się te dzieci uczą" ${ }^{\prime \prime 5}$.

\section{ZAKOŃCZENIE}

Po 1400 latach istnienia kościoła chrześcijańskiego w Mosulu, w mieście nie jest odprawiana msza święta - nie ma tu ani jednego chrześcijanina. „Chrześcijanie zastanawiają się, gdzie jest świat i dlaczego nikt nie chce nam pomóc. Gdzie jest rząd, gdzie są inni ludzie, dlaczego nikt nic z tym nie robi" ${ }^{56}$ - między innymi takie pytania zadał Fadi, iracki chrześcijanin, któremu wraz z rodziną udało się uzyskać status uchodźcy we Francji.

Wielu jednak nie ma tyle szczęścia. „W moim kraju bycie martwym to czasem dobry wybór" ${ }^{\prime 5}$ - zaznaczył ks. Douglas Bazi. Pomimo nalotów na cele Państwa Islamskiego, rozpoczętych przez Stany Zjednoczone w sierpniu 2014 roku, sytuacja chrześcijan w Iraku nie uległa poprawie. Amerykanie w czerwcu 2015 roku wysłali na Bliski Wschód kolejnych 450 żołnierzy, oprócz 3000 już stacjonujących w kraju, w celu szkolenia irackich sił wojskowych do walki $z$ ISIS ${ }^{58}$. Jak przyznał w telewizji CBS generał Ray Odierno, szef Sztabu Generalnego USA, samo amerykańskie szkolenie nie wystarczy - potrzebne jest poczucie jedności na irackiej scenie politycznej - jedności do pokonania ISIS: „to, czego potrzebujemy, to zintegrowana armia złożona z sunnitów, szyitów i Kurdów, którzy będą tam dla Iraku i chętni do walki o Irak. Kiedy to będzie załatwione, możemy trenować ich i pomóc im, ale zanim nie będą w stanie sami stworzyć armii, która będzie reprezentować wszystkich, to będzie trudne zadanie"59.

Pokonanie ISIS, a jednocześnie zatrzymanie brutalnej eksterminacji ludności chrześcijańskiej i innych mniejszości narodowych będzie według ekspertów bardzo trudne: „To są ludzie, którzy w dzień pracują normalnie, a w nocy wyruszają na patrole, na checkpointy - więc jak teraz odróżnić zwykłego Araba od bojownika ISIS? Wojskowo ISIS jest bardzo sprawny, silny, dostosowany do warunków klimatycznych i krajobrazowych, jakie tam panują, do topografii. Pokonanie ISIS to nie jest pstryknięcie palcem - żadne

${ }^{54}$ Testimony: Tom Malinowski, dz. cyt.

${ }^{55}$ Rozmowa z ks. Waldemarem Cisłą.

${ }^{56}$ Rozmowa z grupą irackich uchodźców.

${ }^{57}$ Rozmowa Skype z ks. Douglasem Bazi.

${ }^{58}$ Gen. Odierno on troop increase: „I don't think it's a new strategy”, CBS News, 11.06.2015, http://www. cbsnews.com/news/general-ray-odierno-president-obama-iraq-troop-increase-strategy-combat-isis/ (8.07.2015).

${ }^{59}$ Gen. Odierno on troop increase: „I don't think it's a new strategy”, dz. cyt. 
oddziały amerykańskie nie zostaną wypuszczone do walki z ISIS, bo będą ogromne straty. ISIS mogą pokonać tylko milicjanci szyiccy z południa i Kurdowie z północy"60. Według Witolda Gadowskiego rozpad Iraku jest nieunikniony: „Irak i tak musi być podzielony. Irak w tym kształcie, w jakim został narysowany przez Brytyjczyków po I wojnie światowej, nie przetrwa - musi zostać wydzielona część sunnicka, część szyicka i autonomiczny Kurdystan, który już praktycznie stał się państwem samodzielnym"61.

Według relacji ks. Baziego iraccy chrześcijanie tracą nadzieję na powrót do swoich domów i normalne życie: „Po pierwsze chciałbym powiedzieć, że moi ludzie nie są źli na Boga za to, co się stało. Dziękują Bogu, że ocalił ich rok temu. Ale nie jesteśmy aniołami, patrzymy w przyszłość. Dzień po dniu tracimy nadzieję. Każdy może żyć z bólem, można się do niego przyzwyczaić, ale jeśli nie masz nadziei lub czegoś, o czym mógłbyś przyszłościowo myśleć, to jest to dla ciebie koniec życia"62.

Chrześcijanie iraccy, pozbawieni domów i majątków, w zdecydowanej większości chcą opuścić Irak; mała skuteczność zachodniej interwencji nie daje nadziei na szybkie rozwiązanie konfliktu. „Zwykle ujmuję to w trzech zdaniach: módlcie się za nas, pomóżcie nam i ocalcie nas. Módlcie się za nas, by moi ludzie pozostali silni i czuli, że nie zostali przez innych zapomniani. Pomóżcie nam, by moi ludzie mogli żyć w godności, nie mówię o jedzeniu, nikt tu nie umiera z głodu. Pomóżcie nam mieć znowu dom, edukację i opiekę zdrowotną. I wreszcie - ocalcie nas - powtarzam to od roku, mimo że wielu próbowało mnie uciszyć - a ja powtarzam, otwórzcie drzwi swoich krajów dla moich ludzi” - zaapelował ks. Douglas Bazi, zwracając szczególną uwagę na przyjęcie irackich uchodźców przez zachodnią społeczność.

Eksterminacja chrześcijan na terenie Bliskiego Wschodu jest celowym atakiem na wyznawców Chrystusa w celu całkowitej eliminacji ich życia, kultury i dziedzictwa na Bliskim Wschodzie. Islamscy przywódcy ISIS konsekwentnie w ciągu roku doprowadzili do całkowitego wyparcia chrześcijan z ich największej w Iraku enklawy - Mosulu, a także Karakoszu i innych miejscowości, gdzie chrześcijanie byli obecni od pierwszych wieków.

Działania Państwa Islamskiego w świetle Konwencji ws. zapobiegania i karania zbrodni ludobójstwa ONZ należy uznać za ludobójstwo, popełniane w każdym z wymiarów wymienionych w dokumencie Narodów Zjednoczonych z 1948 roku. Konwencja jednakże nie podaje konkretnych środków, jakie należy przedsięwziąć w celu zapobieżenia dalszym aktom ludobójstwa. Według Konwencji: „Każda z Umawiających się Stron może zwrócić się do właściwych organów Narodów Zjednoczonych o przedsięwzięcie przewidzianych w Karcie Narodów Zjednoczonych środków, które uznają za odpowiednie dla zapobieżenia i stłumienia aktów ludobójstwa lub innych czynów wymienionych w Artykule III"63 - zatem to po stronie państw - członków ONZ leży wezwanie do reakcji na sytuację mniejszości religijnych na terenie Iraku. Organem najbardziej właściwym do zasygnalizowania odbywającego się w Iraku ludobójstwa byłby rząd iracki, którego terytorium zajęło Państwo Islamskie. Szyicko-sunnicki rząd Hajdera al-Abadiego z trudem

\footnotetext{
${ }^{60}$ Rozmowa z reportażystą Witoldem Gadowskim.

${ }^{61}$ Rozmowa z reportażystą Witoldem Gadowskim.

${ }^{62}$ Rozmowa przez Skype z ks. Douglasem Bazi.

${ }^{63}$ Konwencja ws. zabobiegania i karania zbrodni ludobójstwa, dok. cyt.
} 
jednak powstrzymuje kolejne zdobycze terrorystów, sytuacja mniejszości religijnych nie znajduje się zatem w pierwszoplanowej agendzie spraw do rozwiązania.

Od początku działań Państwa Islamskiego Watykan wzywa do ostrej reakcji na nie przede wszystkim muzułmańskich duchownych. Już w sierpniu 2014 roku Papieska Rada ds. Dialogu Międzyreligijnego zażądała od przedstawicieli religii islamskiej potępienia barbarzyństw dżihadystów z Państwa Islamskiego, podkreślając, że „żadne przyczyny, a już na pewno nie religia, ich nie usprawiedliwiają"64. Papieska Rada wymieniła w dokumencie działania przedstawicieli Państwa Islamskiego, nazywając je „wyjątkowo poważną obrazą ludzkości i Boga”. W dokumencie wspomniano m.in. „okrutną praktykę ścinania głów, krzyżowania oraz wieszania zwłok ludzkich w miejscach publicznych [...], uprowadzanie kobiet i młodych dziewcząt należących do społeczności jazydów w charakterze łupu wojennego (sabaja) [...], barbarzyńską praktykę infibulacji (zszywanie warg sromowych) [...], skrajną przemoc w celu terroryzowania"65.

Papieska Rada wezwała również przedstawicieli religii do wywarcia wpływu na rządy, „by ukarały sprawców zbrodni, przywróciły państwo prawa na całym terytorium, sprowadziły z powrotem osoby z niego wygnane" ${ }^{\text {"66 }}$.

W marcu 2015 roku podczas modlitwy na Anioł Pański papież Franciszek potępił „brutalność ISIS, niedającą się tolerować” i wezwał „wszystkich, w ramach ich możliwości, by działać na rzecz ulżenia w cierpieniach" ludzi będących prześladowanymi przez ISIS $^{67}$.

Słowo „ludobójstwo” wobec eksterminacji chrześcijan i innych mniejszości religijnych na terenie Babilonu do tej pory rzadko jednak pojawiało się w publikacjach na łamach prasy i artykułów naukowych. Regularnie używają go aktywiści zajmujący się prawami człowieka mniejszości religijnych, a także księża zamieszkujący i odwiedzający Bliski Wschód. Prestiżowy internetowy portal zajmujący się sprawami międzynarodowymi - Foreign Policy użył słowa „ludobójstwo” w najnowszym artykule dotyczącym czystek dokonywanych przez ISIS w Tikricie. W czerwcu 2014 roku, gdy ISIS zajął miasta uznawane niegdyś za bastion prezydenta Saddama Husseina, dokonał masowej egzekucji szyickich policjantów i strażników - według szacunków organizacji Human Rights Watch mogło tam jednorazowo zginąć od 550 do 770 mężczyzn ${ }^{68}$. 24 bojowników Państwa Islamskiego podejrzanych o udział w masakrze zostało w lipcu 2015 roku skazanych przez iracki sąd na karę śmierci.

„ONZ znalazło dowody, że w niektórych przypadkach Państwo Islamskie może być winne zbrodni ludobójstwa, ale dopóki zbrodnie te nie zostaną zbadane przez wiarygodny trybunał, osoby podejrzewane o współudział będą sądzone przez szemrany iracki wymiar

${ }^{64}$ Watykan chce wyraźnego potępienia Państwa Islamskiego przez muzułmanów, „Gazeta Wyborcza” 12.08.2014, http://wyborcza.pl/1,91446,16467461,Watykan_chce_wyraznego_potepienia_Panstwa_Islamskiego. html\#ixzz3fNOLSTVr (9.07.2014).

${ }^{65}$ Watykan chce wyraźnego potępienia Państwa Islamskiego przez muzułmanów, dz. cyt.

${ }^{66}$ Watykan chce wyraźnego potępienia Państwa Islamskiego przez muzułmanów, dz. cyt.

${ }^{67}$ Pope Francis condemns 'intolerable brutality' of ISIS, „Catholic Herald” 2.03.2015, http://www.catholicherald.co.uk/news/2015/03/02/pope-francis-condemns-intolerable-brutality-of-isis/ (9.07.2015).

${ }^{68}$ S. O'Grady, A Massacre So Bloody It Could Be Seen From Space, „Foreign Policy” 8.07.2015, http:// foreignpolicy.com/2015/07/08/a-massacre-so-bloody-it-could-be-seen-from-space/?wp_login_redirect=0 (9.07.2015). 
sprawiedliwości - gdzie podejrzani w tej sprawie mieli według raportów zasłaniane oczy i byli skuci kajdankami, zanim skazano ich na karę śmierci”" 9 .

Pokonanie Państwa Islamskiego może być procesem długotrwałym i skomplikowanym - Irak i Syria to dziś miejsca, gdzie mieszają się strefy wpływów wielkich mocarstw i państw regionu. Jedyną organizacją mogącą przeprowadzić na tych terenach operację międzynarodową jest ONZ, jednak jest ona złożona $\mathrm{z}$ indywidualnych państw i to one muszą stworzyć koalicję przeciwko ISIS. Wyjście z impasu wydaje się obecnie trudne do przewidzenia. Jak konkluduje ks. Waldemar Cisło: „ patriarcha Babilonii i zwierzchnik Kościoła chaldejskiego - patriarcha Saako przyznał w rozmowie ze mną, że pierwszy raz w historii mają taką sytuację że nie wiedzą co robić" ${ }^{\prime 70}$.

Dziesiątkowanie chrześcijan na Bliskim Wschodzie jest w fazie apogeum. Spośród 1,5 miliona wyznawców Chrystusa w regionie na terenie Iraku i Syrii pozostało najwyżej 10 proc. tej liczby. Nieustające brutalne działania Państwa Islamskiego, a także spóźniona i niewystarczająca reakcja mocarstw regionalnych, jak i zachodnich powoduje, że nadzieje na poprawę sytuacji są w najbliższym czasie znikome.

\section{LITERATURA}

Benedykt XVI, Adhortacja Ecclesia in Medio Oriente, 2012.

Church Bombings in Iraq Since 2004, Assyrian Int'l News Agency, http://sverigesradio.se/ diverse/appdata/isidor/files/83/6810.pdf (7.07.2015).

http://edition.cnn.com/2014/07/24/world/iraq-violence/ (8.07.2015).

http://foreignpolicy.com/2014/08/14/is-the-islamic-state-exterminating-the-language-of-jesus/ (8.07.2015).

http://foreignpolicy.com/2015/07/08/a-massacre-so-bloody-it-could-be-seen-from-space/? wp_login_redirect $=0$ (9.07.2015).

http://gosc.pl/doc/1787870.Bliski-Wschod-pozostanie-bez-chrzescijan (9.07.2015).

http://news.bbc.co.uk/2/hi/middle_east/3527032.stm (7.07.2015).

http://www.bbc.com/news/world-middle-east-28814633 (8.07.2015).

http://www.bbc.com/news/world-middle-east-32287806 (8.07.2015).

http://www.catholicherald.co.uk/news/2015/03/02/pope-francis-condemns-intolerable-bru tality-of-isis/(9.07.2015).

http://www.cbn.com/cbnnews/world/2014/August/Fleeing-Yazidis-Face-Uncertain-Future/ (8.07.2015).

http://www.cbsnews.com/news/general-ray-odierno-president-obama-iraq-troop-increasestrategy-combat-isis (8.07.2015).

http://www.christianpost.com/news/23863/\#eluXbbCmRV60KsTd.99 (7.07.2015).

http://www.foxnews.com/opinion/2014/12/16/iraqs-quiet-christian-genocide.html (7.07.2015).

http://www.independent.co.uk/news/world/middle-east/iraq-crisis-un-warns-yazidis-re fugees-trapped-on-mount-sinjar-are-facing-imminent-genocide-from-is-militants- $9665003 . h t m l$ (8.07.2015).

\footnotetext{
${ }^{69}$ S. O'Grady, A Massacre So Bloody It Could Be Seen From Space, dz. cyt.

${ }^{70}$ Rozmowa $\mathrm{z}$ ks. Waldemarem Cisło, dz. cyt.
} 
http://www.independent.co.uk/news/world/middle-east/isis-executed-scores-of-children-ina-year-of-its-caliphate-10352256.html (8.07.2015).

http://www.nytimes.com/2010/11/02/world/middleeast/02iraq.html?_r=2\&scp=3\&sq=anthony $\% 20$ shadid\&st=cse (7.07.2015).

http://www.nytimes.com/2010/11/02/world/middleeast/02iraq.html?_r=2\&scp=3\&sq=anthony \%20shadid\&st=cse (7.07.2015).

http://www.opoka.org.pl/biblioteka/W/WP/jan_pawel_ii/listy/tertio.html\# (7.07.2015).

http://www.thedailybeast.com/articles/2013/09/27/a-global-slaughter-of-christians-butamerica-s-churches-stay-silent.html (7.07.2015).

http://www.theguardian.com/world/2014/jun/10/iraq-sunni-insurgents-islamic-militantsseize-control-mosul (7.07.2015).

http://www.theguardian.com/world/2014/jun/30/isis-announces-islamic-caliphate-iraq-syria (6.07.2015).

http://wyborcza.pl/1,91446,16467461,Watykan_chce_wyraznego_potepienia_Panstwa_Islam skiego.html\#ixzz3fNOLSTVr (9.07.2014).

Konwencja ws. zabobiegania i karania zbrodni ludobójstwa, New York, 9.12.1948.

Kosińska K., Polityczne i prawne regulacje dotyczace zbrodni ludobójstwa, Toruń 2008.

Moore J., Defying ISIS, Nashville 2015.

Prześladowani i zapomniani. Raport o prześladowaniach chrześcijan w latach 2011-2012, red. W. Cisło, Warszawa 2013.

Rozmowa z grupą irackich uchodźców mieszkających tymczasowo we Francji, Lourdes, 4.05.2015.

Rozmowa z ks. Douglasem Bazim, opiekunem diecezji w stolicy Kurdystanu, Irbilu, prowadzącym centrum uchodźców i szkołę dla ich dzieci, 5.05.2015 (rozmowa przez Skype).

Rozmowa z ks. prof. UKSW dr. hab. Waldemarem Cisłą, dyrektorem sekcji polskiej Pomoc Kościołowi w Potrzebie, Warszawa, 22.04.2015.

Rozmowa z reportażystą Witoldem Gadowskim, Kraków, 13.06.2015.

Testimony: Tom Malinowski, Assistant Secretary, Bureau of Democracy, Human Rights, and Labor, As-Prepared Opening Statement, House Foreign Affairs Subcommittees on Africa, Global Health, Global Human Rights and International Organizations and the Middle East and North Africa, Washington, DC, September 10, 2014, http://www.state.gov/j/drl/rls/rm/2014/231483.htm (7.07.2015).

Weiss M., Hassan H., ISIS - inside and army of terror, New York 2015. 